\title{
Ultralyd for å diagnostisere pneumothorax
}

Nils Petter Oveland disputerte mandag 21. oktober 2013 for ph.d.-graden ved Universitetet i Bergen med avhandlingen:

Ultrasound Detection of Pneumothorax Development of a porcine pneumothorax model to assess and teach lung ultrasound diagnostics.

Ved thoraxtraume er det risiko for pneumothorax. Luft i pleuraspalten kan føre til kompresjon av hjerte og den uskadete lungedelen, slik at pasienten får sterk åndenød og i verste fall hjertestans.

Den adekvate og forholdsvis enkle behandlingen er pleuradrenasje med hjelp av en nål eller et plastikkdren, slik at luften slippes ut fra pleuraspalten. Problemet er, at det kan være vanskelig å stille den rette diagnosen, både ved klinisk undersøkelse og røntgen av thorax.

I avhandlingen ble bruken av bærbare ultralydapparat sammenlignet med røntgen og computertomografi (CT). Videre ble legestudenter undervist $i$ ultralyd av lungene, for å se om de uten tidligere erfaring kunne lære seg metoden. Siden strålefa- ren ved gjentatte røntgenmålinger utelukket undersøkelser av "ekte" pasienter i studien, ble en eksperimentell grisemodell utviklet.

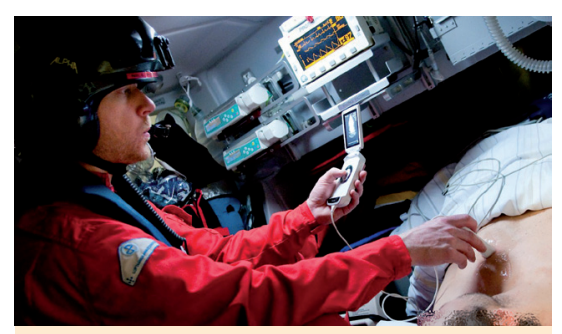

Nils Petter Oveland

En fant at ultralyd i motsetning til et vanlig røntgenbilde av thorax kan oppdage selv små mengder luft rundt lungen. Ultralyd var nesten like nøyaktig som dagens gullstandard CT, for å vurdere mengden av luft inni brysthulen og til å oppdage endringer i størrelsen av punkterte lunger over tid. Legestudenter lærte seg raskt å diagnostisere pneumothorax med høy nøyaktighet.

Konklusjonen er at ultralyd er en nøyaktig og rask undersøkelse uten strålebelastning. Med dagens teknikk kan undersøkelsen utføres nærmest overalt og uten tidsforsinkelse. Teknikken er enkel å lære og bør ses på som et naturlig tillegg til dagens kliniske undersøkelse av traumepasienter. På bakgrunn av denne forskningen brukes ultralyd i dag som et "visuelt stetoskop" i luftambulansetjenesten i Norge.

Styret gratulerer styremedlemmet Nils Petter med disputas. 